\title{
The impacts of the sulphur emission regulation on the sulphur emission abatement innovation system in the Baltic Sea region
}

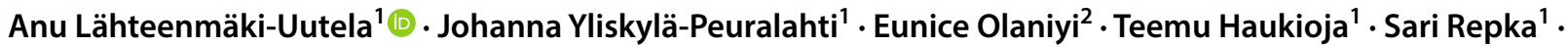 \\ Gunnar Prause ${ }^{2}$. Olena De Andres Gonzalez ${ }^{1}$
}

Received: 9 October 2018 / Accepted: 6 March 2019 / Published online: 22 March 2019

(c) The Author(s) 2019

\begin{abstract}
According to the Porter hypothesis, regulations on environmental emissions under certain conditions can promote ecoinnovation. This is why the technological innovation systems (TIS) theory sees regulatory pressure as a major system function critical in the take-off phase. In other words, the design and timing of any regulation may be decisive for the regulatory outcome. The research seeks to provide empirical evidence on how the Baltic Sea Sulphur Emission Control Area (SECA) has impacted the technological innovation system within the Baltic Sea Region maritime sectors. The results (1) show that regulatory compliance gave a knowledge development that has made it possible for clean-tech companies to engage in entrepreneurial activities that created new markets, (2) empirically support the TIS theory and the Porter hypothesis, and (3) provide qualitative evidence on how businesses see environmental regulation.
\end{abstract}

\section{Graphical abstract}

The innovation system for ship sulphur emission abatement.

\begin{tabular}{|l|l|l|}
\hline \multicolumn{2}{|c|}{ Institutions: environmental law and politics + social norms } \\
\hline $\begin{array}{l}\text { Research: universities \& } \\
\text { private R \& D } \\
\begin{array}{l}\text { Education: higher education } \\
\text { and professional training }\end{array}\end{array}$ & Supply: & Demand: \\
& $\begin{array}{l}\text { Emission monitoring } \\
\text { services }\end{array}$ & Shipping companies \\
\hline \multicolumn{2}{|c|}{ Support organizations: } \\
financing, innovation support, \\
shipping industry associations, network associations
\end{tabular}

Keywords Eco-innovation $\cdot$ Environmental regulation $\cdot$ Technological innovation system (TIS) $\cdot$ Sulphur

\footnotetext{
Anu Lähteenmäki-Uutela

anmlaht@utu.fi

1 University of Turku, Turku, Finland

2 Tallinn University of Technology, Tallinn, Estonia
} 


\section{Introduction: environmental regulation and eco-innovation}

Environmental regulations are borne out of the need to create solutions to specific environmental problems and to protect the environment and human lives (Olaniyi 2017). Currently, there is a strong interest in global seafaring to limit ship emissions such as carbon dioxide $\left(\mathrm{CO}_{2}\right)$, sulphur oxides (SOx), ozone-depleting substances (ODS), particulate matters (PA), volatile organic compounds (VOC) and nitrogen oxides (NOx), especially in the coastal areas (IMO 2016). This study focuses on the innovation impacts of the sulphur legislation which was made to reduce SOx and PA from shipping.

Occasionally, at the introduction of new regulations, there may be concerns on the negative impacts that the law could have on some groups of people or businesses, and that it even can be counterproductive (Rebelo 1991). In a different light, Solow (1994) makes it clear that all economic progress depends on knowledge creation, R\&D activities, and innovations along with a suitable regulatory environment. In other words, regulation can accelerate innovation and technology transfer as a by-product or as its very goal.

Panagakos et al. (2014) emphasised the importance of fortifying regulations and environmental awareness to stimulate innovation. Also with the sulphur regulations concerning the maritime sector, it is interesting whether they can be linked directly or indirectly to the technological responses and compliance actions. Market demand for eco-innovation and societal demand for environmental regulation necessarily intertwine, as they both are based on the values of citizens. A regulatory move can trigger responses and evoke shortterm reactions to long-term proactive strategies, it forces firms to revise their production possibilities, practices, the organisation of activities, and all the aspects of their business plans in order to survive in competition (Porter 1991). On another hand, sometimes, environmental demand can be stronger from the markets than from governments, and even in highly regulated markets, there may be (a niche) demand for above-the-law green solutions. In Triguero et al. (2016), most companies admitted that their eco-innovations were influenced by existing or expected regulation or access to subsidies and tax incentives. Companies studied by Triguero et al. see themselves as responding also to environmental demand and not only to existing regulations. In any case, environmental demand can be seen as the antecedent for environmental regulation. For example, according to Panagakos et al. (2014), a business environment can be changed by some external force be it from regulations or market demand. More so, regulatory demands can also be seen as market or business environmental demands. The demand for green products can push companies to eco-innovate.
Kemp and Pearson (2007, p. 7) define eco-innovation as 'the production, application or exploitation of a good, service, production process, organisational structure, or management or business method that is novel to the firm or user and results throughout its life cycle in the reduction of environmental risk, pollution and negative impacts of resource use (including energy use) compared to relevant alternatives'. At the firm-level, eco-innovation is studied in capacities, motivations, processes, and strategies that explain eco-innovation. Several researchers focus on networks and knowledge systems that are required for eco-innovation. Iansiti and Levien (2004) stress that the success of the company will depend on the success of the business ecosystem. Besides internal R\&D, firms acquire codified and tacit knowledge from external sources through their relationships (Tödtling et al. 2006). Sometimes, a firm may need technical assistance from outside for creating the capacity to comply with pollution prevention regulation (Khanna et al. 2009). Planko et al. (2016) state that to commercialise sustainable innovations, collective systems building is required. Roscoe et al. (2016) suggest that 'strong ties with strategic suppliers will lead to the development of incremental ecoinnovations while weak ties with multiple suppliers and with suppliers that bridge structural holes will tend to lead to radical eco-innovations'. Proximity (cognitive, organisational, social, institutional, and geographical) can promote learning and innovation between companies, but too much proximity can lead to technological lock-in (Boschma 2005). Institutional proximity means that firms located in one region usually operate in a similar institutional context (Grillitsch et al. 2015, p. 37), i.e. they share the same rules and values (Boschma 2005, p. 68). In consequence, technological knowledge is required for adapting to environmental demands (Canon De Francia et al. 2007).

Societal rules and values impact the functions of the innovation system, and this interplay between green technologies and society is studied in the Technological Innovation System (TIS) approach. The TIS framework is a functional approach for analysing the dynamics within a technological innovation system (Bergek et al. 2008). Hekkert et al. (2007) earlierly presented the innovation systems approach as a new framework for analysing technological change. This framework is meant to be used by policymakers as a practical scheme of analysis. The innovation system analysis allows policymakers to identify the weak parts of the innovation system where impactful societal intervention is needed (Jacobsson and Bergek 2011).

Most likely, stringent environmental standards of the Baltic Sea SECA have encouraged R\&D, not only where the regulation is in force, but also in countries where there are previous developments for these technologies and industries. The primary goal of this paper is to study the impact of the sulphur regulations on eco-innovation and the technological 
innovation system of the Baltic Sea Region. Using the Technological Innovation System (TIS) approach by Hekkert et al. (2007) and the Porter hypothesis (1995) on environmental regulation, the study highlights how the sulphur regulations induced efficiency and encouraged innovations that have helped the improvement of commercial eco-innovation in the BSR. First, the study uses the Porter hypothesis to suggest that strict sulphur regulation in the BSR provoked innovative technological push for the BSR that has brought about efficiency and environmental reformation. Further, following the TIS theory, the study accentuates the role of the mandatory sulphur regulations on the technological innovation system for products or processes that result in the reduction of sulphur emissions from shipping activities. The TIS theory to this degree serves as a framework for gaining an understanding of the socioeconomic interplay between environmental regulations and eco-innovation.

The research activities involved secondary data analysis, expert interviews and case examples of companies' innovation through the study of exhibition data and the patent data from shipping companies and maritime public authorities. All activity carried out in the frame of 'EnviSuM'-Environmental impact of low emission shipping measurements and modelling strategies project sponsored by the BSR Interreg Programme. We conclude that a regulation limiting ship sulphur emissions can promote eco-innovation in emission abatement technology and that the SECA regulation may have promoted other types of innovation as well, but the latter are outside the scope of this paper. This empirical finding supports the TIS theory and the Porter hypothesis. It provides qualitative knowledge on how businesses themselves see environmental regulation. The study is structured in the following manner: Chapter two describes the TIS theory and the Porter hypothesis for presenting the theoretical background on the relationship between environmental regulation and eco-innovation. The SECA Rules and the research question are presented in chapter three. The fourth chapter explains the research methods used. The fifth chapter presents the results, and the last section draws conclusions and discusses the results.

\section{TIS theory and the Porter hypothesis}

A technological innovation system is defined as the set of actors and rules that influence the speed and direction of technological change in a specific technological area' (Hekkert et al. 2007). In the assessment of technological innovation systems, it is important to recognise the actors, institutions, networks, and technology that make up that system. The central actor categories are knowledge institutes, educational organisations, industry, market actors, and government bodies. Institutions are the rules the society is built on including formal (legal) and informal (social) rules. The networks consist of connections between the actors while technological structures consist of artefacts and infrastructures (Hekkert et al. 2011). Binz and Truffer (2017) see the Global Innovation System as consisting of 'actor networks and institutional contexts that jointly support (or hinder) the formation and diffusion of innovation' (Binz and Truffer 2017, p. 1286). Innovative products and services emerge more often because of a cross-sectorial combination of technologies, design and business models (Olaniyi and Prause 2016).

The functions of the system are the target of attention in the innovation system analysis: they describe what is happening in the system (Markard and Truffer 2008). The functions (subprocesses) contribute to the overall goal of the system, which is the creation and utilisation of innovations. By analysing the functions separately, both efficient and dysfunctional parts are noticeable, which helps to evaluate how well the system as a whole is functioning (in relation to societal goals). According to Hekkert et al. (2007), the following functions of the innovation systems are central: Entrepreneurial activities, Knowledge development, Knowledge exchange, Guidance of the search, Formation of markets, Mobilisation of resources, and Creating legitimacy (Counteracting resistance to change). Guidance of the search means that changing preferences in society if they are strong and visible, can influence $\mathrm{R} \& \mathrm{D}$ priority setting and thus the direction of technological change (Hekkert et al. 2007). Market formation means that firms will only invest if they believe in a clear future market. Weaknesses in the 'Guidance of the search' function and the 'Market formation' function are often due to institutional weaknesses (Jacobsson and Bergek 2011). Environmental regulation has a role in influencing specific necessary functions within an innovation system: It can strengthen the incentives and pressures for organisations to enter the technological field, facilitate market formation, and strengthen the social acceptance of the innovation through legitimation.

Hekkert et al. (2011) explained that in the TIS theory, different functions are critical for different phases of development. For example, in the predevelopment phase, knowledge development is of high priority. In the development phase, the weight shifts to entrepreneurial experimentation. For the take-off phase, entrepreneurial experimentation and counteracting resistance to change are critical. Hekkert emphasised that guidance of the research, resource mobilisation and market formation are likewise important. Guidance of the research means regulations, visions, and expectations from government and key actors. Clear policy goals regarding the technological field can represent strong guidance for the innovation system. Resource mobilisation refers to the sufficiency of human and financial resources, and market formation means whether the current or expected market size is sufficient to support entrepreneurial activity. Lastly, 
as international regulation that can force technological change may be needed to make the markets large enough, at the acceleration phase, the market formation is the most important system function.

In the static business environment and in the short run, environmental policies change the competitive situation of current firms and influencing the competitiveness of businesses positively or negatively. In the long run, with possibilities to adaptation, the negative effects can be reversed (Tietenberg and Lewis 2012, pp. 546-547). According to the 'Porter hypothesis', environmental regulation can improve companies' competitiveness and mitigate compliance costs by motivating resource efficiency and new innovations (Porter and van der Linde 1995a, b). In 'A Dictionary of Environmental Economics, Science, and Policy' by Grafton et al. (2001, p. 218) the Porter hypothesis is defined as 'the assumption that environmental regulations can stimulate innovation and increase productivity by providing incentives for individuals and firms to develop new production processes'. According to Porter and van der Linde (1995a, b), international competitiveness is a dynamic concept based on innovation; Ambec and Barla (2006) conclude that there is only weak evidence according to which environmental regulations would stimulate innovation activity; André et al. (2009) provide theory-based support for the Porter hypothesis in competitive framework; and later Ambec et al. (2013) conclude that the empirical evidence gives support to the hypothesis that stricter environmental regulation leads to more innovation, but whether it can enhance business performance gives mixed results. Environmental regulation may promote eco-innovation through that it:

(a) Signals to companies about resource inefficiencies and better available technologies (reducing emissions is technologically possible),

(b) Reduces the uncertainty regarding the value of environmental investments (the investment can be justified),

(c) Levels the playing field and helps overcome coordination problems within the industry (the whole industry needs to reduce emissions),

(d) Creates pressure that motivates action (emissions need to be reduced now),

(e) Helps to overcome biases of managers (even a riskaverse and present-biased manager may decide to reduce emissions).

Incremental eco-innovations are modifications to existing products or services (e.g. a more fuel-efficient vessel engine) (Roscoe et al. 2016). Incremental innovations result from a step-by-step co-evolutionary process of change (Ashford and Hall 2011) that builds upon existing production system and customer base (see Christensen 1997). Radical innovations create disruption and replace existing technologies, dominant firms, user demand and established production systems. Radical innovations thus cause system changes which extend outside the boundaries of a single firm and involve the reorganisation of entire production chains and stakeholder networks, including also regulators, end-users and citizens. A systemic change simultaneously changes production, employment, distribution, and transportation (Ashford and Hall 2011).

Ambec et al. (2013) provide causal links, or the simplest 'model', describing the Porter hypothesis. The societal 'impulse' for business innovations is 'strict but flexible environmental regulations'. The firms must response to such requirements by investing in innovation activities if they are to continue on business. The consequent innovations can be divided into those that mainly affect 'environmental performance' or 'business performance', but some sort of mixed innovation is also possible.

Porter (1991) claims that environmental regulation mainly makes current businesses (regulation targets) innovate on cost reductions, increases in productivity, production processes, and logistics. For this study, this includes the shipping companies and existing vessel engine providers. On another premise, regulations may also make new businesses to innovate on new products and services, where the pricequality ratio and customer satisfaction, according to Porter (1991), would be more important factors than plain costs or productivity. On the other hand, current businesses may react to regulation by radical innovation or by increasing competitiveness by quality, whereas new companies may be based on incremental innovation, plain cost reduction, or on disseminating innovation that is new to its user but not new to the world.

The Porter hypothesis shows a possibility to get both lower emissions and welfare effects for the society, and competitive advantages to industries or economies. Although there are no simple and established cause-effect relationships between stricter environmental regulations and innovation/competitiveness, some studies have found empirical support to this hypothesis, while others give no support for it. The literature discusses the weak, narrow, and strong versions of the Porter hypothesis. Barbera and McConnell (1990) find that the net impact of environmental regulations on total factor productivity growth is fairly small; Jaffe and Palmer (1997) find that environmental compliance expenditures have a significant positive effect on $R \& D$ expenditures, but they find only little evidence that industries' successful patent applications would be related to compliance costs.; Lanoie et al. (2011) can find strong support for the 'weak' version of the Porter hypothesis, qualified support for the 'narrow' version of it, but no support for the 'strong' version. According to De Santis and Jona-Lasinio (2015) tighter environmental regulation affects productivity and innovation, and the weak form oh the Porter hypothesis cannot 
be rejected. The main conclusion in the literature is that a strict but flexible environmental policy in connection with economic incentives indeed contributes to eco-innovation.

\section{The SECA rules and the research questions}

According to the current Baltic Sea Sulphr Emission Control Area (SECA) rules, the ships operating in the Area must only use marine fuels containing max $0.10 \%$ sulphur. This regulation came into force at the beginning of 2015. The regulation is regional: the areas affected are the Baltic Sea, The North Sea, Hawaii, and East and West coasts of the USA and the Caribbean Sea. As with other regulations, the SECA regulations were planned long before they were decided upon, and they came into force even later (Olaniyi et al. 2018). Currently, the global sulphur cap of $3.5 \%$ on fuel is implemented for ships outside the SECAs. This requirement has been renegotiated by IMO to be lowered to $0.5 \%$ from 2020 onwards.

The timing of regulations and the certainty or uncertainty on its timing may be decisive for the impacts of the regulation in the technological innovation system (Kivimaa 2007). Regarding the SECA rules, companies with cleantech solutions may need to build their capabilities and networks before they can offer good-quality products or services. The assumption of this study is that the current Baltic Sea SECA rules may have influenced companies' strategies, R\&D efforts, and innovation outcomes at the times of:

(a) The committee work at the IMO from 2005 to 2007 while evaluating the IMO sulphur rules (ECG 2013),

(b) The decision on the stricter IMO sulphur rules (2008)

(c) The entering into force in $2010,{ }^{1}$

(d) The decision on the stricter EU SECA rules in 2012, ${ }^{2}$ and/or

(e) The entering into force of a stricter EU SECA rules in 2015.

Dynamic efficiency typically requires that a regulation leave open the technology or process for reaching the regulatory goal, thus promoting market innovation in finding the solutions (Lanoie et al. 2011). The European directive does allow

\footnotetext{
${ }^{1}$ Modifying Annex VI to MARPOL. Annex VI was added to MARPOL in 1997 and has been modified several times. The decision on the Baltic Sea SECA (1.5\% Sulphur) was made in 2005 . The decision on the stricter rules ( $0.1 \%$ sulphur) was made in 2008 and it entered into force in 2010. It applied to harbours, if the vessel stayed there for more than $2 \mathrm{~h}$. It also applied to inland waters.

2 Directive 2012/33/EU of the European Parliament and of the Council of 21 November 2012 amending Council Directive 1999/32/EC as regards the Sulphur content of marine fuels.
}

various methods for reaching the regulatory goal: in addition to using low-sulphur marine fuel, the directive mentions onboard exhaust gas cleaning systems, the mixture of fuel and liquefied natural gas (LNG), or the use of biofuels (preamble 24 of the Directive 2012/33/EU). The legal text assumes that markets will develop alternative technologies for lowering the sulphur emissions.

Along with the environmental and health impacts, innovation impacts may represent one of the major positive impact categories of the SECA rules (Lähteenmäki-Uutela et al. 2016). Horbach et al. (2011) have previously found that for innovation related to reducing air, water and noise emissions, government regulation is a particularly important determinant. When the marketing system interacts with the regulatory system, it typically results in changes in the output of the marketing system (Layton 2007). In the SECA case, the desired change is marine transport services in the Baltic Sea region with lower sulphur emissions.

It may be somewhat difficult to separate the impacts of the SECA regulation from many other environmental regulations targeting the shipping companies. However, the SECA rules were very radical in their time and the first that really induced some costs on the shipping industry. We, therefore, see the SECA rules as a particularly relevant study target.

The research question here (following the definition of eco-innovation by Kemp and Pearson 2007) is whether and how the SECA rules have impacted the eco-innovation system. The theoretical focus is in the power of a regulatory move to force or speed up eco-innovation. Our definition includes in eco-innovations that

(1) lead to lower sulphur emissions from ships,

(2) are either radical (including systemic) or incremental and

(3) are novel to the firm or user (not necessarily new in the world).

The study further probes what type of eco-innovations the SECA regulation has speeded up, by whom (which and what type of companies are involved), where (geographically), when, and why (how do companies see the SECA regulation to motivate/benefit themselves).

\section{Methods}

To organise the potentially innovative solutions to sulphur emission abatement, focal maritime exhibitions and patents were studied. To complement the exhibition data and the patent data, an interview study was conducted within BSR companies. The interviews deepen the understanding of the motivational relationships between the regulatory system and the innovation system within the examined business. 


\section{Study I: product and service offerings at maritime exhibitions}

The study targeted three maritime exhibitions in Europe: NEVA (Russia), SMM (Germany) and Nor-Shipping (Norway). These exhibitions had the biggest turn out rates of exhibitors and were quite popular in the Baltic Sea region. Exhibitors that attended between 2013 and 2017 were examined for such product and service offerings that aimed at meeting the SECA rules. In total, eight exhibitions were evaluated: NEVA'13, NEVA'15, NEVA'17, Nor-Shipping'13, Nor-Shipping' 15, Nor-Shipping'17, SMM'14, and SMM'16. This allowed the study to evaluate the offerings both before the entering into force of the SECA regulation and after.

\section{Study II: patents}

Using the premise by Jaffe and Palmer (1997) that patents can be used as an indicator of inventive output, patent analysis in the Baltic Sea region was carried out to track the pace of R\&D and the development of innovative technologies. Patents are used for this purpose as they are publicly available and by definition related to innovation (Griliches 1998). Technological inventions are patentable if they are new, possess an inventive step compared to the previous level of knowledge, and have industrial applicability. A patent is a right to prohibit others from using the same invention on the geographical area to which the patent applies. Companies, sectors, and countries can be compared as in who patents the most, but a patent by itself does not provide an indication of the relative importance and impact of the invention in question (Haščič and Migotto 2015). Lanjouw and Mody (1996), De Vries and Withagen (2005), and Brunnermeier and Cohen (2003) studied the influence of environmental regulation on patenting. They all conclude that the influence is rather weak, but these papers considered the general patenting activity without specifying its direction. Hascic et al. (2009) and Johnstone et al. (2010) analysed the impact of public policy on innovations in the area of renewable energies in the OECD countries. They concluded that the impact of environmental regulation on innovation and patenting depends on whether the regulation creates a new market where innovating and patenting is deemed profitable. We scrutinise whether we can recognise the impacts of SECA on patenting activity.

\section{Study III: interviews}

The innovation system functions are evaluative in character, and qualitative methods, e.g. interviews with key players, are needed for gaining knowledge on these functions and context for innovation (Kemp and Pontoglio 2011). For a
Table 1 Companies studied at maritime exhibitions in Europe

\begin{tabular}{lll}
\hline Company & Country & Keyword \\
\hline ABB Marine and Ports & Sweden & Emission monitoring \\
Aker Arctic Technology Inc & Finland & Shipbuilding \\
Alfa Laval & Sweden & Scrubber \\
Babcock Noell GmbH & Germany & Scrubber \\
Blue Ocean Solutions Pte Ltd & Finland & Scrubber \\
Danfoss IXA A/S & Denmark & Emission monitoring \\
Gazprom-Neft Marine Bunker & Russia & Marine diesel oil (MDO) \\
Gold Engineering GmbH & Germany & Emission monitoring \\
Lukoil Bunker & Russia & Marine diesel oil (MDO) \\
MAN Marine Engines and & Denmark & LNG \\
Systems & & \\
ME Production A/S & Denmark & Scrubber \\
PureteQ & Denmark & Scrubber \\
Rosneft Bunker & Russia & Marine diesel oil (MDO) \\
Saacke GmbH & Germany & Scrubber \\
Scandinavian Boiler Service & Denmark & Emission monitoring \\
A/S & & \\
TECHNOLOG Services GmbH & Germany & LNG \\
TX Marine Messsysteme & Germany & Emission monitoring \\
GmbH & & \\
Wärtsilä Corporation & Finland & Scrubber \\
\hline
\end{tabular}

deeper understanding of how and why the SECA rules have impacted innovation, this study targeted twelve resource efficiency companies listed below, of which seven are scrubber companies and five are measurement technology companies). Five scrubber companies and one measurement technology company responded to the invitation to interview. They were asked about the R\&D efforts, the environmental benefits of their products and services, and specifically about how the regulation has impacted the demand.

\section{Results: the impact of the SECA on eco-innovation}

\section{Results of study 1: exhibitions}

Table 1 shows the 18 companies that were studied because they presented their products or services at the maritime exhibitions. Table 2 shows the descriptions of their SECArelated products or services.

These companies participated in one to eight exhibitions. Rosneft Bunker Company has not taken part in any of the named exhibitions but it was included in the list because together with Lukoil and Gazprom, the company is among the main Russian suppliers of maritime fuel (bunker) in the Baltic Sea region.

The list of the companies studied includes five German, five Danish, three Finnish and two Swedish industrial 
Table 2 SECA-related product or service descriptions

\begin{tabular}{|c|c|c|}
\hline Company & Foundation year & Product description \\
\hline ABB Marine and Ports & 1987 & Retractable $\mathrm{pH}$ sensors \\
\hline Aker Arctic Technology Inc & 2005 & $\begin{array}{l}\text { Polaris is the most environmentally friendly diesel-electric icebreaker...uses both low } \\
\text { sulphur diesel and LNG as fuel, which significantly reduces its emissions }\end{array}$ \\
\hline Alfa Laval & 1883 & $\begin{array}{l}\text { Alfa Laval Pure Sox is the only complete SOx scrubber platform...over } 40 \text { years of } \\
\text { marine scrubber experience... secure compliance while using HFO }\end{array}$ \\
\hline Babcock Noell GmbH & 2000 & $\begin{array}{l}\text { A broad range of environmental technologies including...flue gas desulphurisation, } \\
\text { purification and denitrification }\end{array}$ \\
\hline Blue Ocean Solutions Pte Ltd & 2010 & $\begin{array}{l}\text { The BOS Emulsified Fuel System improves the combustion efficiency...fuel savings of } \\
\text { between } 2 \text { and } 5 \% . . . \text { results in cleaner exhaust }\end{array}$ \\
\hline Danfoss IXA A/S & 2009 & $\begin{array}{l}\text { Continuous measurement of emission gases directly in the exhaust system....accurate } \\
\text { real-time measurements of NOx and SOx... will enable the ship to prove compliance in } \\
\text { case the port state control requests this information }\end{array}$ \\
\hline Gazprom-Neft Marine Bunker & 2007 & A wide range of bunker fuels (1) RMD-80 0.1\% (2) Marine oils \\
\hline Gold Engineering GmbH & 2010 & Continuous emissions monitoring system (Emsys $\left.{ }^{\mathrm{TM}}\right)$ \\
\hline Lukoil Bunker & 1998 & Marine Diesel Oil (MDO), Marine Gas Oil (MGO) \\
\hline MAN Marine Engines and Systems & 1980 & $\begin{array}{l}\text { The purpose of the marine fuel gas system is to fill, store and vapourise LNG and to } \\
\text { supply natural gas to engines on a ship }\end{array}$ \\
\hline ME Production A/S & 1995 & MEP-SOx Scrubber solution reduces emissions of SOx \\
\hline PureteQ & 2010 & $\begin{array}{l}\text { PureteQ Maritime Turbo Scrubber is a high-tech scrubber system for the purification of } \\
\text { flue gas from maritime engines and boilers. Hydrodynamic fluid distribution ensures } \\
\text { optimal absorption of sulphuric acid and particles }\end{array}$ \\
\hline Rosneft Bunker & 2010 & Distillate or Marine Diesel Oil (MDO) and Marine Gas Oil (MGO) \\
\hline Saacke GmbH & 1931 & Scrubber for exhaust gas cleaning: EGCS-HM \\
\hline Scandinavian Boiler Service A/S & 1997 & $\begin{array}{l}\text { Smoke Density Monitor is designed to... monitor smoke emissions from all kinds of } \\
\text { combustion...patented technology.... a reliable and effective information tool }\end{array}$ \\
\hline TECHNOLOG services GmbH & 1979 & $\begin{array}{l}\text { LNG is quickly becoming the alternative of choice... drastic reduction in emissions } \\
\text { compared to fuel oil }\end{array}$ \\
\hline TX Marine Messsysteme GmbH & 2013 & $\begin{array}{l}\text { Measurement equipment based on electrochemical sensors is the optimal tool for use on } \\
\text { board }\end{array}$ \\
\hline Wärtsilä Corporation & 1834 & Scrubbers certified according to the IMO guidelines... safe operation and compliance... \\
\hline
\end{tabular}

companies along with three Russian oil companies. Estonian, Latvian or Lithuanian companies did not present relevant products or services at these fairs. The main alternatives for SECA compliance are fuel switch and scrubbers. In addition, emission-monitoring services are a visible category present at fairs.

Most companies presenting SECA-related solutions are old. Wärtsilä and Alfa Laval are the oldest ones. Established companies that already serve the maritime industry have enlarged their product and service portfolio to meet the demand for emission abatement technologies (Alfa Laval, ABB, Wärtsilä), cleaner fuels (Rosneft, Lukoil), shipbuilding (Aker Arctic) and emission monitoring (Danfoss) either via in-house R\&D development or acquisition of other companies. These companies serve global markets and a whole range of other industries besides maritime transport, so they have just adjusted their already existing technologies to a new field.

The introduction of emission restrictions has very likely influenced the founding of the companies that have been established since 2010_Blue Ocean Solutions, Gold Engineering Gmbh, PureteQ, and TX Marine Messsysteme (Table 3). Besides maritime and offshore sectors, many of these new entrants serve a whole range of other polluting industries since the similar emission reduction technology is applicable for both power plants and marine engines. Although these companies are small (most have 10 employees or less), they serve global markets. TX Marine Messsysteme is the newest (youngest) company on the list.

Blue Ocean Solutions produces emulsified fuel systems (EFS) for marine diesel engines that assure 2-5\% fuel savings and reduced NOx and PM emissions. The company is a subsidiary of Keppel Offshore and Marine, one of the world's biggest offshore and marine companies. The mother company designs, constructs and repairs offshore rigs, and conducts building, repair and conversion of specialised vessels. Company headquarters are located in Singapore, and the production of EFS systems and division of European sales in Helsinki, Finland. Though its mother company Blue Ocean Solutions is networked to 20 yards and offices 
Table 3 Description of four new companies Data sources: Company websites and maritime news sources (listed in references), Orbis business database

\begin{tabular}{|c|c|c|c|c|c|}
\hline Company & $\begin{array}{l}\text { Main products and } \\
\text { services }\end{array}$ & Location & Number of employees & Main markets & Turnover (EUR) \\
\hline Blue Ocean Solutions & $\begin{array}{l}\text { Production of emulsified } \\
\text { fuel systems (EFS) and } \\
\text { engine performance } \\
\text { software }\end{array}$ & $\begin{array}{l}\text { Helsinki, Finland (HQ in } \\
\text { Singapore) }\end{array}$ & 2 (in Finland) & Global & 99,000 \\
\hline Gold Engineering Gmbh & $\begin{array}{l}\text { Technical service and } \\
\text { consulting for marine- } \\
\text { and power diesel } \\
\text { engines, reconditioned } \\
\text { and new spare parts for } \\
\text { vessels' diesel engines, } \\
\text { monitoring systems } \\
\text { for fuel and propulsion } \\
\text { efficiency for vessels } \\
\text { and power plants }\end{array}$ & Hamburg, Germany & 19 & $\begin{array}{l}\text { Global marine } 55 \% \\
\text { offshore } 20 \% \\
\text { energy } 20 \%\end{array}$ & \\
\hline PureteQ & $\begin{array}{l}\text { Emission reduction tech- } \\
\text { nologies for shipping } \\
\text { and energy production }\end{array}$ & $\begin{array}{l}\text { Svendborg, Denmark } \\
\text { (sales office in Ham- } \\
\text { burg, Germany) }\end{array}$ & 12 & Global & \\
\hline TX Marine Messsysteme & $\begin{array}{l}\text { System provider for } \\
\text { measuring equipment } \\
\text { for power plants and } \\
\text { vessel engines }\end{array}$ & $\begin{array}{l}\text { Kiebitzreihe (Hamburg } \\
\text { region), Germany }\end{array}$ & 4 & Global & $1,200,000$ \\
\hline
\end{tabular}

globally (Blue Ocean Solutions 2017; World cruise industry review 2017).

Blue Ocean Solutions was established in 2010 to offer solutions for shipowners to improve energy efficiency and emission reductions. Forthcoming regulations (EEDI, SECA) and high bunker prices (in 2010) contributed to the establishment of the company. Global sulphur cap and MRV directive have increased the demand for its products and services. The company is a research spin-off: the founder of the company Dr. Ng Kok Loon was working as a research assistant in 1980s in a pioneering research team who tested of emulsified fuel to marine diesel engines at the University of Newcastle while working on his doctorate degree. He continued his research work at the Nanyang Technological University in Singapore, with the support of the National Science Council and Neptune Orient Lines. Currently, Dr. $\mathrm{Ng}$ has two patents relating to emulsified fuel technology with several more pending (Blue Ocean Solutions 2017; Cleantech Finland 2017; Finnish Marine Industries 2017).

Gold Engineering Gmbh was founded in 1995. The company provides spare parts and bearing shells for the vessel's main and auxiliary engines, monitoring systems for fuel and propulsion efficiency for vessels and power plants, and energy efficiency consulting. The company's success as a spare parts supplier and engine specialist has given it a unique reputation in the marine market and has helped enlargement into new business areas, such as clean technology. Company's clean technology solutions offered to ships include propulsion efficiency measurement systems
(EVOthrust ${ }^{\mathrm{TM}}$ ), fuel efficiency controller (FEC), and continuous emissions monitoring system (Emsys ${ }^{\mathrm{TM}}$ ). The company serves worldwide markets. Over half (55\%) of the sales comes from marine, $20 \%$ from offshore industries, and $20 \%$ from the energy sector. Since 2005, the company has collaborated with Singapore-based green technology company DIMAR-TEC. According to the company's webpage, environmental regulations and demands for lower costs drive the market for the company's products and services (Gold Engineering GmbH 2017).

PureteQ is part of the Dansk Synergi group, with headquarters, testing facilities and production in Svendborg Denmark and sales office in Hamburg, Germany. The company was founded in 2010. Company's main technologies include the purification of process water from industry, the energy sector and oil and gas sector, the purification and heat recovery of flue gas from highly polluting industries, including biomass-fired combined heat and power plants, and energy utilisation of liquid industrial by-products, hazardous waste and other alternative fuels with low calorific value and high water content. The company conducts research and development and has several patents for its technologies. PureteQ has developed, manufactured and patented an entirely new scrubber system for the purification of flue gas. The company also collaborates with international maritime consultancy, Erria A/S, which specialises in the development and supervision of new building projects, refurbishments, and ship design (PureteQ 2017). The introduction of SECA in 2015 and global sulphur regulations that are coming in force 
Table 4 Patents on air emission abatement from mobile sources Source: OECD database (Lithuanian data is not available)

\begin{tabular}{lrrrrrrrrrrrr}
\hline & 1990 & 2000 & 2005 & 2006 & 2007 & 2008 & 2009 & 2010 & 2011 & 2012 & 2013 & 2014 \\
\hline Finland & 2 & 12 & 15 & 11 & 10 & 13 & 12 & 16 & 31 & 22 & 19 & 30 \\
Denmark & 4 & 4 & 18 & 21 & 20 & 24 & 10 & 22 & 15 & 23 & 20 & 27 \\
Estonia & & & & 1 & & & 1 & & 10 & 7 & 1 & \\
Germany & 477 & 1300 & 1431 & 1508 & 1509 & 1695 & 1473 & 1414 & 1327 & 1341 & 1303 & 1232 \\
Latvia & & & 1 & & 1 & 1 & 3 & 1 & 2 & & 1 & \\
Sweden & 11 & 40 & 70 & 78 & 89 & 54 & 58 & 73 & 59 & 76 & 73 & 55 \\
Poland & 17 & 5 & 8 & 14 & 15 & 2 & 16 & 11 & 23 & 32 & 20 & 20 \\
All & 511 & 1361 & 1543 & 1633 & 1644 & 1789 & 1571 & 1537 & 1467 & 1501 & 1437 & 1364 \\
\hline
\end{tabular}

in 2020 have increased demand for the company's products in the maritime industry.

TX Marine Messsysteme GmbH provides measuring equipment for power plants and vessel engines. The founders of the company, Paschen family, have a long-term technical and market experience on technical measuring and analysis equipment for ships and power plants. The company first started as a sales company for measuring equipment but has since 2017 provided consulting, delivery of the measurement technology, service and after sales support (including user training). Company's main products and services include performance monitoring (shaft power, indicator, emission measurement), condition monitoring (pressure and temperature calibrator, endoskop), fuel monitoring (fuel counter, mechanical and coriolis), and fuel treatment (changeover units). Company's own developments include thrust and torque measurement systems (TORXmeter shaft power measuring system and EVOthrust thrust and torque measuring system) (TX Marine 2013).

\section{Results of study 2: patents}

Going further into detail on the SECA-related technological innovation, we studied some patents. The OECD has its database on innovation in environment-related technologies. It uses data extracted from the Worldwide Patent Statistical Database (PATSTAT) of the European Patent Office (EPO) by algorithms developed by the OECD. The 'technology development' indicator lists patents in various fields. 'Air emission abatement' has the subcategory 'Emissions abatement from mobile sources'. Table 4 shows the patents by Baltic Sea region countries in this category.

Among the Baltic Sea region countries, Germany has the newest patents annually (over 1200). In absolute terms, Germany clearly has a steady R\&D tradition on air emission abatement. Sweden, Denmark, Finland and Poland hold the following positions. In relation to country sizes, Germany is still twice as active as Sweden, Denmark and Finland. Patenting activity is negligible in the Baltic countries. The table above includes patents on air emission abatement from cars, which is particularly relevant for the German automobile industry, and for Sweden. Unfortunately, for the purpose of this study, there is no subcategory for air emission abatement from ships. The table still tells us that several Baltic Sea region companies had considerable know-how in air emission abatement before the entering into force of the SECA rules. Passing regulations on ship emissions would presumably be considered legitimate in societies where air emission abatement already is a part of the technological environment and where air quality has already been recognised as an important societal value.

The IPC system by the World Intellectual Property Organization WIPO classifies inventions into more than 70,000 technological groups and subgroups. The Espacenet is a free patent database where one can search for example based on patent categories. It contains 80 million patents from all over the world. By using Espacenet, we found exhaust gas scrubber patents that have been filed in the IPC categories B63H 21/32, B B01D53/14 and B01D 53/18.

The international patent category $B$ is for 'Performing operations, transporting'

B63 is 'Ships and waterborne vessels; related equipment', $\mathrm{B} 63 \mathrm{H}$ is 'Marine propulsion or steering',

B63H 21/00 is 'Use of propulsion power plant or units on vessels', and

B63H 21/32 is 'Arrangements of propulsion power-unit exhaust uptakes'.

In the precise subcategory $\mathrm{B} 63 \mathrm{H} 21 / 32$, there are 2533 patents or patent applications. As an example, one of the patent applications by company Wärtsilä, filed in 2014, is described as this:

An arrangement for treating exhaust gases of an internal combustion piston engine in a marine vessel includes an exhaust gas channel coupled at its first end to the engine and having its second end opening to the environment, and a scrubber unit arranged between the first end and the second end of the exhaust gas channel. The arrangement has an exhaust gas channel cleaning system arranged to apply cleaning liquid on the inner 
surface of the exhaust gas channel to a portion of the exhaust gas channel between the scrubber unit and the second end of the exhaust gas channel.

In the same category, Alfa Laval has a patent that was filed in 2014 and granted in 2018:

A cleaning system for reducing SOx and particulate matter in exhaust gases from a marine combustion engine, burner or boiler. The cleaning system comprises first and second scrubber process loops having first and second scrubber, respectively, and first and second water circulation tanks, respectively. Water from the first tank is evaporated to water vapor inside the first scrubber by contact with the exhaust gases, whereby the water vapor and the exhaust gases form humid exhaust gases. The humid exhaust gases are transferred to the second scrubber, wherein water from the second tank condensates the water vapor in the humid exhaust gases. Reflux of water from the second scrubber process loop to the first scrubber process loop is provided. At least $60 \%$ and more preferred at least $90 \%$ of the total amount of alkaline agent supplied to the cleaning system is supplied to the second scrubber process loop.

Under category B 'Performing operations, transporting'

B01 is 'Physical or chemical processes or apparatus in general'

B01D is 'Separation'

B01D 53/00 is 'Separation of gases or vapours; Recovering vapours of volatile solvents from gases; Chemical or biological purification of waste gases, e.g. engine exhaust gases, smoke, fumes, flue gases, aerosols', and

B01D53/14 is 'Separation of gases or vapours by absorption'

B01D 53/18 is 'Absorbing units' and

In the category B01D53/14, Babcock Noell GmbH has in 2017 filed a patent for 'A gas scrubber, in particular for desulphurising flue gases, preferably for installation on a ship, having a scrubber housing and a gas pipe arranged underneath the scrubber housing for guiding the gas to be scrubbed in the scrubber housing, wherein the scrubber housing has a scrubber chamber delimited by a scrubber base, a scrubber head and a scrubber shell provided between the scrubber base and the scrubber head. In order to achieve more reliable operation, it is provided that a gas supply for the lateral introduction of gas via at least one opening into the scrubber chamber is provided in the region of the scrubber shell'.

These examples show patenting activity surrounding the marine exhaust gas cleaning systems before and after the entering into force of the 2015 SECA. Companies have been innovative and added to previous technology. The texts of the patent applications describe the regulatory demands as a driver for the sulphur emission abatement inventions.

\section{Results of study 3: interviews}

Results from the interviews show that environmental legislation in general and specific regulations to restrict vessel exhaust gas emissions both at the regional level (SECA) and forthcoming global SOx regulations (coming in force in 2020) have influenced the development of scrubber technology. The shipping industry is a major customer for companies providing emission reduction technology. The technologies of the interviewed companies help shipping companies meet the regulations set by the IMO. Global regulations create global markets. One interviewee said they have six or seven different technologies, all related to environmental legislation. Another interviewee said they have several environmental R\&D subprojects and an ongoing $\mathrm{R} \& \mathrm{D}$ effort related to SOx and carbon emissions. Two companies said they were focusing primarily or purely on sulphur regulations.

All of the companies benefit from emission regulation and see it as an opportunity for themselves and their customers. Regulation is seen as the major (or only) driver for the scrubber market. For the biggest companies, sales expected from new products and related services are worth billions in euro, and markets are global. Some companies started selling their technology first to regional markets in the Baltic Sea and North Sea SECA, and expect that the forthcoming global SOx emission and carbon regulations will increase the demand of their products and services. The main business opportunities resulting from new environmental regulation are related to the creation and expansion of the markets. When the decision on the new regulation is made, and especially, when it is in force, regulation targets search for solutions. All the interviewees see that without the regulation, none of the customers would buy emission reduction technology. As some of the respondents said, if they were no regulation, no one would be interested in their products. Therefore, it was the regulations that promoted the demand for companies' products and services as the regulations made ship owners seek for innovative environmental solutions.

On the other hand, inadequate enforcement of environmental regulations is also one of the biggest threats to eco-innovative companies. Regulation only impacts the markets if it has credible control mechanisms and sanctions (Lähteenmäki-Uutela et al. 2019). Some emission technology providers are dissatisfied with the present maritime emission regulations and enforcement. When the SECA regulation regarding maritime $\mathrm{SOx}$ emissions was designed, there was not enough knowledge on how to monitor the 
Table 5 The innovation system on sulphur emission abatement for ships Source: adapted from Hekkert et al. (2011)

Institutions: environmental law and politics + social norms

Research: universities and private $\mathrm{R} \& \mathrm{D}$

Education: higher education and professional training

Supply:
Fuel companies
Scrubber companies
Emission monitoring services

Demand:

Shipping companies

Emission monitoring services

Support organisations: financing, innovation support, shipping industry associations, network associations

exhaust gas cleaning to ensure compliance with the regulations. Some companies see that the enforcement of the regulation regarding SOx emissions has not sufficient and that the sanctions for non-compliance are too small. For example, one respondent said that enforcement and fines are not sufficient. Sometimes the offending businesses can save up to $\$ 100,000$, but fines are barely $\$ 10,000$. Together with high costs required to ensure compliance with emission regulations, shipping companies have thus high incentives not to follow the rules. All these issues are harming the business of the emission technology providers.

Other challenges mentioned are overcoming the skepticism towards the reliability of clean technology, possible future regulation that would make current technology inadequate, and possible problems with finding skilled labour for the clean-tech companies. The companies who provide technology for the shipping industry need to monitor that industry closely. If the shipping markets are going down, or if shipping companies otherwise cannot afford to buy technology, it negatively affects the economy of the technology providers. In addition, the technology provider companies mention that scrubber technology is closely tied with keeping heavy fuel as the main energy source for ships. However, due to a pressing need to cut greenhouse gas emissions and development of other 'cleaner' energy sources, it is likely that the use of heavy fuel oil in shipping will be reduced in the future. For companies providing scrubber technologies, that type of trend is bad news.

\section{Discussions and conclusions}

The study set out to understand whether and how the SECA rules have impacted the production, application or exploitation of eco-innovations within the Baltic Sea region innovation system. Applying the technological innovation systems (TIS) theory as instructed by Hekkert et al. (2011), the authors conclude that the SECA regulation represents or is a part of a systemic change at the societal level that is making environmental technologies widely accepted within the maritime industries. The basic structure of the TIS for ship sulphur emission abatement consists of institutions, research, education, supply, demand, and support organisations (Table 5).
Similarly to Ashford et al. (1985), Türpitz (2004) and Bergek and Berggren (2014), it was found that environmental regulation changes the market and forces innovation. Boons and Lüdeke-Freund (2013) stress that the markets for eco-innovations need to be deliberately created. The clean-tech businesses clearly see that the market for sulphur emission abatement in ships has been created by the SECA regulation (even though the same technology has been used in land-based factories and facilities for years). Regulation is the main driver for eco-innovation in the field of ship sulphur emission. A green regulatory push from the public sector was required in this case. This is an important finding that supports the TIS theory and the Porter hypothesis. This study provides qualitative evidence on how businesses see environmental regulation.

In view of the necessary technological innovation system functions listed by Hekkert et al. (2011), the origin of sulphur emission abatement is traced to knowledge development. In recent years, patents for sulphur emission abatement have granted to several companies in different countries. Knowledge exchange between science and the industry is represented in projects such as EnviSuM. ${ }^{3}$ The size and importance of the SECA areas have been large enough to create incentives for entrepreneurial activities. The SECA regulation has been the main guidance of the search leading to market formation. The regulatory push has been particularly critical for the take-off phase, as suggested by the theory. The innovation system has been able to mobilise resources and to counteract resistance to change.

In addition to the type of regulation chosen (mandatory international rules in the SECA case), the innovation impacts of environmental regulation may greatly depend on the design and implementation features of the regulation (Kemp and Pontoglio 2011, p. 34). Like Kemp and Pontoglio (2011, p. 34) say, a stimulus-response model does not adequately describe the relationship between environmental regulation and the innovation system. This applies to SECA: the regulations for land-based emissions promoted the development of emission abatement technology, which paved the way for the ship emission rules. Understanding the

\footnotetext{
${ }^{3}$ EnviSuM-Environmental Impact of Low Emission Shipping: Measurements and Modelling Strategies.
} 
context is the key to predicting the impacts of regulation. If new rules are significantly more stringent compared to previous rules, they will presumably force more innovation and even radical innovation, as companies face large deficiency gaps in their institutional environments: continuing as before is not possible (Berrone et al. 2013). For a given level of stringency, the more flexible regulations tend to produce a more positive impact on eco-innovation. Predictability of rules (legal certainty) will encourage investment, and compatibility with other policy instruments is recommendable (Kemp and Pontoglio 2011, p. 34). Compliance motivation may be enhanced by credible monitoring and efficient sanctions. Innovators, customers and regulators interact in a system where all parties try to exert influence over the process outcome. The SECA rules are only one of the multiple environmental regulations targeting the maritime industry, a part of a larger international regulatory scheme and shift. This shift towards more stringent rules has started at least a decade ago.

With the case of SECA, many of the design and implementation features (stringency, certainty, timing, flexibility, compatibility, enforcement) seem to have been sufficient to produce the markets for low sulphur fuels, exhaust gas scrubbers, and sulphur monitoring technologies. These innovations are incremental more than radical. The content and design features of the SECA rules in combination with other current and upcoming environmental rules is not enough to make the shipping industry shift entirely to renewable energy for example. Radical or systemic innovation would require a different set of regulatory requirements. The scrubbers are actually preventing or delaying a total disruption of maritime transports industry.

If we didn't do anything to help keep heavy fuel oil as an environmentally friendly solution to marine propulsion, then all our other equipment we provide to the marine sector would be less attractive because they are all related to the heavy fuel oil.

The successful companies in the innovation system have been able and willing to adopt a proactive approach to regulation by employing their competencies and networks (Iansiti and Levien 2004; Planko et al. 2016). Existing businesses have expanded their environmental-friendly product and service portfolios, and new companies have started to provide new technologies and services. From a management perspective, this has required some corporate foresight, corporate planning and organisational change management (Kaivo-oja 2011). The market for scrubbers has been created by the scrubber companies that have invested in R\&D and finally been able to sell their products to shipping companies by overcoming the suspicion on the reliability of the technology. One interviewee defined what the scrubber business is about:
Our primary function is to develop technologies. We are also persuading the market for scrubbers.

Companies that have seized opportunities first may have gained some first mover advantages (Lieberman and Montgomery 1988; Porter and van der Linde 1995a). The companies that now sell products for the SECA regulation are potential clean-tech providers also for complying with the future regulations. The companies look forwards to future environmental rules:

In addition, they [the scrubbers] reduce the particular matter (PM) emission and black carbon emission although that [the reduction of $\mathrm{PM}$ and $\mathrm{BC}$ emissions] is not a legal requirement [yet], only the SOx has been specifically mentioned. Thinking one step ahead.

When assessing the impacts of regulation, one must assess them in relation to a baseline of what would have happened without the regulation. One can speculate that the technological innovations for reducing ship sulphur emissions might have emerged and disseminated even without any government regulation. Customers demand environmental performance if they derive a private benefit from it (Kammerer 2009). If pressure from customers or other supply chain members would have mounted on the shipping business to reduce their environmental footprint, it might have boosted the innovation system. The motivation to eco-innovate could also have come from inside the shipping companies: environmental leadership and managerial concern over the environment have been mentioned as motivators for eco-innovation (Bossle et al. 2016). It seems likely that market forces and managerial concern would have produced the result of improved air quality much slower than what was achieved by the regulation.

The study provides empirical support to the claim that regulations can have a significant impact on the innovation take-off phase. It has become very pertinent to regulate the environmental impacts of shipping and to promote technological development for effective eco-innovations. Several new shipping regulations are on the way and evaluations on the compliance rates of future regulations are optimistic, even though challenges for compliance monitoring are even greater at high seas than in the Baltic Sea region. Regulators should consider the findings like ours for future environmental law-making. Regulators and clean-tech companies need each other in creating the markets for solving the environmental problems. In order to invest in R\&D, clean-tech companies need to be able to trust that there will be market demand for their products.

If one wanted to understand all the innovation impacts of the SECA rules, one would need to study several sectors including not only the clean-tech companies but also the regulation targets themselves, the companies that ship 
their goods, and the public sector. In addition to eco-innovation on lowering sulphur emissions, the SECA rules may have speeded up the emergence and the adoption of other eco-innovations such as those related to energy efficiency. In addition, there may be business model innovations and social innovations involved. The TIS theory or the Porter theory focus on the innovation effects triggered by regulatory pushes. The macro-economic net effects are another question: while innovative firms may create competitive advantages, others may have to downsize their businesses.

Acknowledgements Funding was provided by EU Interreg Baltic Sea Region Program. Open access funding provided by University of Turku (UTU) including Turku University Central Hospital.

Open Access This article is distributed under the terms of the Creative Commons Attribution 4.0 International License (http://creativeco mmons.org/licenses/by/4.0/), which permits unrestricted use, distribution, and reproduction in any medium, provided you give appropriate credit to the original author(s) and the source, provide a link to the Creative Commons license, and indicate if changes were made.

\section{References}

Ambec S, Barla P (2006) Can environmental regulations be good for business? Assess Porter Hypothesis Energy Stud Rev 14(2):42-62

Ambec S, Cohen MA, Elgie S, Lanoie P (2013) The Porter hypothesis at 2.0: can environmental regulation enhance innovation and competitiveness? Rev Environ Econ Policy 7(1):2-22

André JF, González P, Portiero N (2009) Strategic quality competition and the Porter hypothesis. J Environ Econ Manag 57:182-194

Ashford NA, Hall RP (2011) The importance of regulation-induced innovation for sustainable development. Sustainability 3(1):270-292

Ashford NA, Ayers C, Stone RF (1985) Using regulation to change the market for innovation. Harv Environ Law Rev 9:419-466

Barbera AJ, McConnell VD (1990) The impact of environmental regulations on industry productivity: direct and indirect effects. J Environ Econ Manag 18(1):50-65

Bergek A, Berggren C (2014) The impact of environmental policy instruments on innovation: a review of energy and automotive industry studies. Ecol Econ 106:112-123

Bergek A, Jacobsson S, Carlsson B, Lindmark S, Rickne A (2008) Analyzing the functional dynamics of technological innovation systems: a scheme of analysis. Res Policy 37:407-429

Berrone Pl, Fosfuri A, Gelabert L, Gomez-Mejia LR (2013) Necessity as the mother of 'green' innovations: institutional pressures and environmental innovations. Strateg Manag J 34:891-909

Binz C, Truffer B (2017) Global innovation systems-a conceptual framework for innovation dynamics in transnational contexts. Res Policy 46(7): 1284-1298

Blue Ocean Solutions (2017) Company www-pages. http://blueoceans oln.com/. Accessed 12/18/2017

Boons F, Lüdeke-Freund F (2013) Business models for sustainable innovation: state-of-the-art and steps towards a research agenda. J Clean Prod 45:9-19

Boschma RA (2005) Proximity and innovation: a critical assessment. Reg Stud 39(1):61-74

Bossle M, Dutra de Barcellos M, Vieira LM, Sauvee L (2016) The drivers for adoption of eco-innovation. J Clean Prod 113:861-872
Brunnermeier SB, Cohen MA (2003) Determinants of environmental innovation in the US manufacturing industries. J Environ Econ Manag 45:278-293

Canon de Francia J, Garces-Ayerbe C, Ramirez-Aleson M (2007) Are more innovative firms less vulnerable to new environmental regulation? Environ Resour Econ 36:295-311

Christensen C (1997) The innovator's dilemma: when technologies cause great firms to fail. Harvard Business School Press, Boston

Cleantech Finland (2017) Member companies: Blue Ocean Solutions. http://www.cleantechfinland.com/-/blue-ocean-solutions. Accessed 18 Dec 2017

De Santis R, Jona-Lasinio C (2015) Environmental policies, innovation and productivity in the EU. LEQS paper no. 100. https://paper s.ssrn.com/sol3/papers.cfm?abstract_id=2696266. Accessed 14 Mar 2019

De Vries FP, Withagen C (2005) Innovation and environmental stringency: the case of sulphur dioxide abatement. Discussion paper, Tilburg University, Tilburg

ECG (2013) Sulfur content in marime fuels. Briefing report. January 2013. http://www.ecgassociation.eu/Portals/0/Documentation/ Publications/ECGBriefingReport_SulphurContent_Jan2013.pdf. (ECG is The Association of European Vehicle Logistics)

EnviSuM (2019) https://projects.interreg-baltic.eu/projects/envis um-16.html. Accessed 15 Feb 2019

Finnish Marine Industries (2017) Blue Ocean Solutions lisää tuotantoaan Suomessa. http://meriteollisuus.teknologiateollisuus.fi/fi/ uutiset/blue-ocean-solutions-lis\%C3\% A4\%C3\%A4-tuotantoaa n-suomessa. Accessed 18 Dec 2017

Gold Engineering GmbH (2017) http://www.gold-engine.eu/golde ngineering-home/. Accessed 18 Dec 2017

Grafton RQ, Pendleton LH, Nelson HW (2001) A dictionary of environmental economics, science, and policy. Edward Elgar, Cheltenham

Griliches Z (1998) R\&D and productivity: the econometric evidence. University of Chicago Press, Chicago

Grillitsch M, Tödtling F, Höglinger C (2015) Variety in knowledge sourcing, geography and innovation: evidence from the ICT sector in Austria. Pap Reg Sci 94(1):25-43

Haščič I, Migotto M (2015) Measuring environmental innovation using patent data. OECD environment working papers, no. 89. OECD Publishing, Paris. http://dx.doi.org/10.1787/5js009kf48xw-en

Hascic I, de Vries F, Johnstone N, Medhi N (2009) Effects of environmental policy on the type of innovation: the case of automotive emission-control technologies. OECD J Econ Stud 2009(1):49-66

Hekkert MP, Suurs RAA, Negro SO, Kuhlmann S, Smits REHM (2007) Functions of innovation systems: a new approach for analysing technological change. Technol Forecast Soc Change 74:413-432

Hekkert M, Negro S, Heimeriks G, Harmsen R (2011) Technological innovation system analysis. A manual for analysts. Unversiteit Utrecht. Faculty of Geosciences. Copernicus Institute for Sustainable Development and Innovation. http://www.innovation-syste m.net/wp-content/uploads/2013/03/UU_02rapport_Technologi cal_Innovation_System_Analysis.pdf. Accessed 14 Mar 2019

Horbach J, Rammer C, Rennings K (2011) Determinants of eco-innovations by type of environmental impact. The role of regulatory push/ pull, technology push and market pull. Ecol Econ 78:112-122

Iansiti M, Levien R (2004) The keystone advantage: what the new dynamics of business ecosystems mean for strategy, innovation, and sustainability. Harvard Business School Press, Boston

IMO (2008) Revised MARPOL Annex VI: regulations for the prevention of air pollution from ships and NOx technical code. IMO Marine Environmental Protection Committee (MEPC), London

IMO (2016) IMO sets 2020 date for ships to comply with low sulphur fuel oil requirement. Press briefing release 28/10/2016. http://www.imo. org/en/MediaCentre/PressBriefings/Pages/MEPC-70-2020Sulphu r.aspx. Accessed 30 November 2016 
Jacobsson S, Bergek A (2011) Innovation system analyses and sustainability transitions: contributions and suggestions for research. Environ Innov Soc Transit 1(1):41-57

Jaffe AB, Palmer K (1997) Environmental regulation and innovation: a panel data study. Rev Econ Stat 79(4):610-619

Johnstone N, Hascic I, Popp D (2010) Renewable energy policies and technological innovation: evidence based on patent counts. Environ Resour Econ Eur Assoc Environ Resour Econ 45(1):133-155

Kaivo-oja J (2011) Futures of innovation systems and systemic innovation systems: towards better innovation quality with new innovation management tools. Finland Futures Research Centre eBook. https://www.utu.fi/fi/yksikot/ffrc/julkaisut/e-tutu/Documents/eTutu 2011_8.pdf. Accessed 14 Mar 2019

Kammerer D (2009) The effects of customer benefit and regulation on environmental product innovation. Empirical evidence from appliance manufacturers in Germany. Ecol Econ 68:2285-2295

Kemp, Pearson (eds) (2007) Final report MEI project about measuring eco-innovation. https://search.oecd.org/env/consumption-innovation 143960830.pdf. Accessed 12 Sept 2017

Kemp R, Pontoglio S (2011) The innovation effects of environmental policy instruments - a typical case of the bind men and the elephant? Ecol Econ 72:28-36

Khanna M, Deltas G, Harrington DR (2009) Adoption of pollution prevention techniques: the role of management systems and regulatory pressures. Environ Resour Econ 44:85-106

Kivimaa P (2007) The determinants of environmental innovation: the impacts of environmental policies on the Nordic pulp, paper and packaging industries. Eur Environ 17:92-105

Lähteenmäki-Uutela A, Repka S, Haukioja T, Pohjola T (2016) How to recognize and measure the impacts of environmental regulation: case SECA. J Clean Prod 154:553-565

Lähteenmäki-Uutela A, Yliskylä-Peuralahti J, Repka S, Mellqvist J (2019) What explains SECA compliance: rational calculation or moral judgment? WMU J Maritime Aff. https://doi.org/10.1007/ s13437-019-00163-1

Lanjouw JO, Mody A (1996) Innovation and the international diffusion of environmentally responsive technology. Res Policy 25(4):549-571

Lanoie P, Lucchetti J, Johnstone N, Ambec S (2011) Environmental policy, innovation and performance: new insights on the Porter hypothesis. J Econ Manag Strategy 20(3):803-842

Layton RA (2007) Marketing systems. A core macromarketing concept. J Macromarketing 27(3):227-242

Lieberman MB, Montgomery DB (1988) First-mover advantages. Strateg Manag J 9(S1):41-58

Markard J, Truffer B (2008) Technological innovation systems and the multi-level perspective: towards an integrated framework. Res Policy 37:596-615

Olaniyi E (2017) Towards EU 2020: an outlook of SECA regulations implementation in the BSR. Balt J Eur Stud 7(2):182-207

Olaniyi EO, Prause GK (2016) Baltic-Russian innovation cooperation in the context of EU eastern partnership. In: Kerikmäe T, Chochia A (eds) Political and legal perspectives of the EU eastern partnership policy. Springer, Cham, pp 257-279

Olaniyi E, Prause G, Boyesen J (2018) The impact of SECA regulations on clean shipping in the BSR. In: Ölçer AI, Kitada M, Dalaklis D, Ballini $\mathrm{F}$ (eds) Trends and challenges in maritime energy management, vol 6. WMU studies in maritime affairs. Springer, Cham, pp 309-323. https://doi.org/10.1007/978-3-319-74576-3

Panagakos GP, Stamatopoulou EV, Psaraftis HN (2014) The possible designation of the Mediterranean Sea as a SECA: a case study. Transp Res Part D Transport Environ 28:74-90

Planko J, Cramer JM, Chappin MMH, Hekkert MP (2016) Strategic collective system building to commercialize sustainability innovations. J Clean Prod 112(4):2328-2341

Porter ME (1991) America's green strategy. Sci Am 264(4):168

Porter ME, van der Linde C (1995a) Toward a new conception of the environment-competitiveness relationship. J Econ Perspect 9:97-118

Porter M, van der Linde C (1995b) Green and competitive: ending the stalemate. Harv Bus Rev 73(5):120-134

PureteQ (2017) Company www-pages. http://www.pureteq.com/. Accessed 18 Dec 2017

Rebelo S (1991) Long-run policy analysis and long-run growth. J Polit Econ 99(3):500-521

Roscoe S, Cousins P, Lamming R (2016) Developing eco-innovation: a three stage typology of supply networks. J Clean Prod 112(3):1948-1949

Solow RM (1994) Perspectives on growth theory. J Econ Perspect $8(81): 45-54$

Tietenberg T, Lewis L (2012) Environmental and natural resource economics, 9 th edn. Pearson, Boston

Tödtling F, Lehner P, Trippl M (2006) Innovation in knowledge intensive industries: the nature and geography of knowledge links. Eur Plan Stud 14(8):1035-1058

Triguero A, Moreno-Mondéjar L, Davia MA (2016) Leaders and laggards in environmental innovation: an empirical analysis of SMEs in Europe. Bus Strategy Environ 25:28-39

Türpitz K (2004) The determinants and effects of environmental product innovations - an analysis on the base of case studies. ZEW discussion paper $04-02$

TX Marine (2013) Company www-pages. http://www.txmarine.com/en/. Accessed 18 Dec 2017

World Cruise Industry Review (2017) Blue Ocean Solutionsincreased fuel efficiency with emulsified fuel. http://www.world cruiseindustryreview.com/contractors/bunkering-fuels-and-lubri cants/blue-ocean-solutions-pte-ltd/. Accessed 18 Dec 2017

Publisher's Note Springer Nature remains neutral with regard to jurisdictional claims in published maps and institutional affiliations. 